\title{
Ammonium chloride enhances cisplatin cytotoxicity through DNA double-strand breaks in human cervical cancer cells
}

\author{
YE XU $^{1,2}$, NING WANG $^{3}$, YAN DING $^{3}$, CHUNYAN WANG $^{1}$, YANG YU $^{1}$, \\ SHIBING LIU ${ }^{1}$, XIAOJUN WANG ${ }^{1}$ and ZHIXIN LI $^{2}$ \\ ${ }^{1}$ Medical Research Laboratory, ${ }^{2}$ Department of Histology and Embryology, \\ and ${ }^{3}$ Clinical College, Jilin Medical College, Jilin 132013, P.R. China
}

Received April 10, 2013; Accepted May 20, 2013

DOI: $10.3892 /$ or.2013.2554

\begin{abstract}
Cisplatin (cis-diamminedichloroplatinum II, CDDP) acts as a therapeutic agent by initiating cellular apoptosis. However, side-effects and drug resistance limit the clinical use of cisplatin. Numerous studies have focused on the drug-target interactions, cellular pharmacology and pharmacokinetics of cisplatin. Newly developed treatment strategies are needed in order to be used in combination with cisplatin, with the aim to minimize toxicity and to circumvent cisplatin resistance. Ammonium chloride $\left(\mathrm{NH}_{4} \mathrm{Cl}\right)$ is widely used in various areas, but its use as a combination agent with cisplatin for the treatment of cancer cells has not been previously reported. In the present study, we showed that $\mathrm{NH}_{4} \mathrm{Cl}$ could be potentially used as an effective agent in cisplatin combination treatment of HeLa human cervical cancer (HCC) cells. Cisplatin was found to inhibit cell growth, as well as to induce cell apoptosis and DNA double-strand breaks. In addition, treatment with $\mathrm{NH}_{4} \mathrm{Cl}$ increased the rate of cell apoptosis and the activation of caspase-3. Particularly, we found that $\mathrm{NH}_{4} \mathrm{Cl}$ treatment increased cisplatin-induced phosphorylation of $\mathrm{H}_{2} \mathrm{AX}$. In conclusion, our data indicate that $\mathrm{NH}_{4} \mathrm{Cl}$ enhances cisplatin cytotoxicity through increased DNA damage in HeLa HCC cells.
\end{abstract}

\section{Introduction}

Cisplatin (cis-diamminedichloroplatinum II, CDDP) is one of the most effective chemotherapeutic agents widely used for the treatment of solid tumors. However, the side-effects of cisplatin chemotherapy and resistance during the course of the treatment limit its clinical use (1-3). Cisplatin is generally considered as a cytotoxic drug which kills cancer cells by damaging DNA and inhibiting DNA synthesis. Cisplatin-induced DNA damage

Correspondence to: Professor Zhixin Li, Department of Histology and Embryology, Jilin Medical College, 5 Jilin Street, Jilin 132013, P.R. China

E-mail: 1zx-62@163.com

Key words: ammonium chloride, cisplatin, apoptosis, $\gamma-\mathrm{H}_{2} \mathrm{AX}$, cervical cancer activates various signaling pathways to prevent or promote cell death predominantly by inducing apoptosis (4). Based on the mechanism of action of cisplatin-induced cell death, modifications to the combination methods used in chemotherapy are required to reduce the side-effects and increase the therapeutic effects of cisplatin. Autophagy inhibitors, such as 3-methyladenine and chloroquine, have been shown to effectively enhance cisplatin cytotoxity (5-8). Additional agents have been recently assessed such as bortezomib (PS-341, Velcade), a proteasome inhibitor $(9,10)$, and histone acetyltransferase inhibitor, suberoylanilide hydroxamic acid (SAHA) $(11,12)$. Some of these agents have been shown to confer sensitizing effects to cisplatin combination therapy.

Ammonium chloride $\left(\mathrm{NH}_{4} \mathrm{Cl}\right)$ is an agent used for the treatment of metabolic alkalosis in clinical practice (13). $\mathrm{NH}_{4} \mathrm{Cl}$ was recently used as an autophagy inhibitor in in vitro studies, where it was found to affect the $\mathrm{pH}$ of lysosomes and to disturb the activity of autolysosomes (14-16). In the present study, we used $\mathrm{NH}_{4} \mathrm{Cl}$ combined with cisplatin to investigate the potentially effective use of $\mathrm{NH}_{4} \mathrm{Cl}$ as an agent in cisplatin combination chemotherapy.

In the present study, we tested the hypothesis that the use of $\mathrm{NH}_{4} \mathrm{Cl}$ increases the apoptosis induced by cisplatin treatment in human cervical cancer (HCC) HeLa cells. Cisplatin was found to inhibit the cell growth, as well as to induce cell apoptosis and DNA double-strand breaks (DSBs). Treatment with $\mathrm{NH}_{4} \mathrm{Cl}$ increased the rate of cell apoptosis and the activation of caspase-3. $\mathrm{NH}_{4} \mathrm{Cl}$ treatment combined with cisplatin was found to increase cisplatin-induced apoptosis by inducing severe DNA damage.

\section{Materials and methods}

Cell culture. The HCC HeLa cell line was cultured at $37^{\circ} \mathrm{C}$ in an atmosphere containing $5 \% \mathrm{CO}_{2}$ and $95 \%$ air, using Iscove's modified Dulbecco's medium (IMDM; Life Technologies, Inc., Gaithersburg, MD, USA) supplemented with $10 \%$ fetal bovine serum (FBS; Gibco-BRL, Carlsbad, CA, USA), 100 U/ml penicillin and $100 \mathrm{U} / \mathrm{ml}$ streptomycin. The cells were divided into 4 groups: non-treated cells, cells treated with $5 \mu \mathrm{g} / \mathrm{ml}$ cisplatin (Sigma, St. Louis, MO, USA), cells treated with $2 \mathrm{mM} \mathrm{NH}_{4} \mathrm{Cl}$ (Sigma) and cells treated with $5 \mu \mathrm{g} / \mathrm{ml}$ cisplatin combined with $2 \mathrm{mM} \mathrm{NH}_{4} \mathrm{Cl}$. 
MTT assay. Cell viability was determined using MTT assay. Exponentially growing HeLa cells were seeded into 96-well culture plates in $100 \mu \mathrm{l}$ medium at a density of $1 \times 10^{4}$ cells/well. After a 24-h incubation, the indicated dose (as described in 'Cell culture') of cisplatin and/or $\mathrm{NH}_{4} \mathrm{Cl}$ was added for a 24-h incubation in 4 parallel wells. MTT assays (Beyotime, China) were subsequently performed. Briefly, $20 \mu \mathrm{l}$ of MTT solution [5 $\mathrm{mg} / \mathrm{ml}$ in phosphate-buffered saline (PBS)] was added followed by a 4-h incubation. Then, $150 \mu \mathrm{l}$ of dimethyl sulfoxide (Beijing Chemical Industry Co., Ltd., China) was added to each well. After shaking for $10 \mathrm{~min}$, absorbance was measured at $570 \mathrm{~nm}$ using a microplate reader (Bio-Rad, Hercules, CA, USA). The survival rate was calculated as follows: Survival rate $(\%)=$ Absorbance of experimental group/Absorbance of control group x $100 \%$. The mean value of 4 wells per treatment group was calculated in each experiment.

Western blot analysis. HeLa whole-cell protein extracts were prepared with cell lysis buffer $(50 \mathrm{mM}$ Tris- $\mathrm{HCl}$, $\mathrm{pH} 7.5,150 \mathrm{mM} \mathrm{NaCl}, 1 \mathrm{mM} \mathrm{Na}{ }_{2}$ EDTA, $1 \mathrm{mM}$ EDTA, $1 \%$ Triton $\mathrm{X}-100,2.5 \mathrm{mM}$ sodium pyrophosphate, $1 \mathrm{mM}$ $\beta$-glycerophosphate, $1 \mathrm{mM} \mathrm{Na} \mathrm{VO}_{4}, 1 \mathrm{mM} \mathrm{NaF}, 1 \mu \mathrm{g} / \mathrm{ml}$ leupeptin and $1 \mathrm{mM}$ PMSF) for western blot analysis. The protein extracts were quantified using the Bio-Rad kit (Pierce). For Western blot analysis, lysate proteins (30-50 $\mu \mathrm{g}$ ) were resolved on $10 \%$ SDS-polyacrylamide gel electrophoresis and transferred onto Immobilon-P transfer membranes (Millipore, Boston, MA, USA). The membranes were blocked with 5\% nonfat dry milk in buffer [10 mM Tris- $\mathrm{HCl}$ (pH 7.6), $100 \mathrm{mM}$ $\mathrm{NaCl}$ and $0.1 \%$ Tween-20] for $1 \mathrm{~h}$ at room temperature. The membranes were then incubated with the appropriate primary antibody [anti-caspase-3 or anti- $\beta$-actin antibody (dilution, 1:200); Eptomics, Burlingame, CA, USA] at $4^{\circ} \mathrm{C}$ overnight, followed by incubation with horseradish peroxidase-conjugated secondary antibody (HuaAn Biotechnology, Hangzhou, China) at a dilution of 1:2,000 for $1 \mathrm{~h}$ at room temperature. The immunoreactive bands were visualized using the diaminobenzidine method (Sigma). Representative bands were measured with a Tanon GIS gel imaging system and analyzed. The levels of proteins were normalized to those of $\beta$-actin and the ratios of normalized protein to $\beta$-actin were presented as means \pm SD from three independent experiments. Protein levels were quantified by densitometry using Quantity One software (Bio-Rad).

Immunofluorescence staining and confocal laser microscopy. Following treatment with the indicated doses of cisplatin and/or $\mathrm{NH}_{4} \mathrm{Cl}$ (as described in 'Cell culture') for $24 \mathrm{~h}$, the cells were cultured on coverslips overnight. Subsequently, the cells were fixed with $4 \%$ paraformaldehyde, cell nuclei were stained with Hoechst 33342 (2 $\mu \mathrm{g} / \mathrm{ml}$; Sigma) for $30 \mathrm{~min}$, followed by washing with PBS. The cells were then observed using Olympus FV1000 confocal laser microscope to examine cell chromatin condensation. The expression levels of active caspase- 3 and $\gamma-\mathrm{H}_{2} \mathrm{AX}$ were examined using an indirect immunofluorescence method. Briefly, the cells were cultured on coverslips overnight, treated with the indicated doses of cisplatin and/or $\mathrm{NH}_{4} \mathrm{Cl}$ (as described in 'Cell culture') for $24 \mathrm{~h}$, and then rinsed thrice with PBS. After incubation, the cells were fixed with $4 \%$ paraformaldehyde for $20 \mathrm{~min}$, permeabilized with $0.1 \%$
Triton X-100 for $5 \mathrm{~min}$, blocked with bovine serum albumin (BSA) and incubated with the primary antibodies against active caspase-3 (Santa Cruz Biotechnology, Inc., Santa Cruz, CA, USA) and $\gamma-\mathrm{H}_{2} \mathrm{AX}$ (Cell Signaling Technology, Inc., Beverly, MA, USA) (dilution, 1:100) at $4^{\circ} \mathrm{C}$ overnight. The cells were then incubated with FITC/Texas Red conjugated secondary antibodies (dilution, 1:400) (Invitrogen, Carlsbad, CA, USA) for $1 \mathrm{~h}$, stained with Hoechst $33342(2 \mu \mathrm{g} / \mathrm{ml})$ for $2 \mathrm{~min}$, and washed thrice with PBS. Following staining, the cells were mounted and examined under a Olympus FV1000 confocal laser microscope.

Flow cytometric analysis. Propidium iodide (PI, $1 \mu \mathrm{g} / \mathrm{ml}$; Invitrogen) was used for the determination of cell death. After exposure to the different experimental conditions, the cells were trypsinized and incubated with PI for $30 \mathrm{~min}$ at $37^{\circ} \mathrm{C}$. The samples were then analyzed using a FACScan flow cytometer (BD Biosciences, Franklin Lakes, NJ, USA). All the experiments were performed in triplicate.

Statistical analysis. Data are representative of three independent experiments each performed in triplicate. Statistical analysis of the data was performed using one-way ANOVA. Tukey's post hoc test was used to determine the significance for all pairwise comparisons of interest. P-values of $<0.05$ were considered to indicate a statistically significant difference.

\section{Results}

$\mathrm{NH}_{4} \mathrm{Cl}$ increases cell growth inhibition induced by cisplatin. Based on the results of our preliminary studies, HeLa cells were treated with the indicated doses of cisplatin and/or $\mathrm{NH}_{4} \mathrm{Cl}$ for $24 \mathrm{~h}$, and cell growth inhibition was then assessed using MTT assays. Cisplatin was found to inhibit the growth of HeLa cells. MTT assays indicated that there was no significant effect of treatment with $\mathrm{NH}_{4} \mathrm{Cl}$ alone on cell viability, while $\mathrm{NH}_{4} \mathrm{Cl}$ enhanced the cytotoxic effect of cisplatin when $\mathrm{NH}_{4} \mathrm{Cl}$ was used in combination with cisplatin (Fig. 1A).

Morphological changes were also examined using an inverted phase contrast microscope. Cisplatin-treated cells were observed to be round and fragile in comparison with the control cells. The number of round and fragile cells following treatment with cisplatin in combination with $\mathrm{NH}_{4} \mathrm{Cl}$ was increased compared to the number of cells exposed to cisplatin alone (Fig. 1B).

Thus, we hypothesized that $\mathrm{NH}_{4} \mathrm{Cl}$ increases the apoptotic rate of HeLa cells induced by cisplatin. The apoptosis rate was then detected by confocal microscopy and flow cytometric analysis.

$\mathrm{NH}_{4} \mathrm{Cl}$ increases cisplatin-induced cell apoptosis. Apoptotic chromatin condensation was assessed with Hoechst 33342 staining and confocal microscopy. Cisplatin-induced apoptotic chromatin condensation was observed in HeLa cells compared with control cells. The cells treated with cisplatin combined with $\mathrm{NH}_{4} \mathrm{Cl}$ exhibited obvious apoptotic chromatin condensation when compared with cells treated with cisplatin alone (Fig. 2A).

The effect of $\mathrm{NH}_{4} \mathrm{Cl}$ on cisplatin-induced apoptosis in HeLa cells was assessed using flow cytometric analysis. As 
A
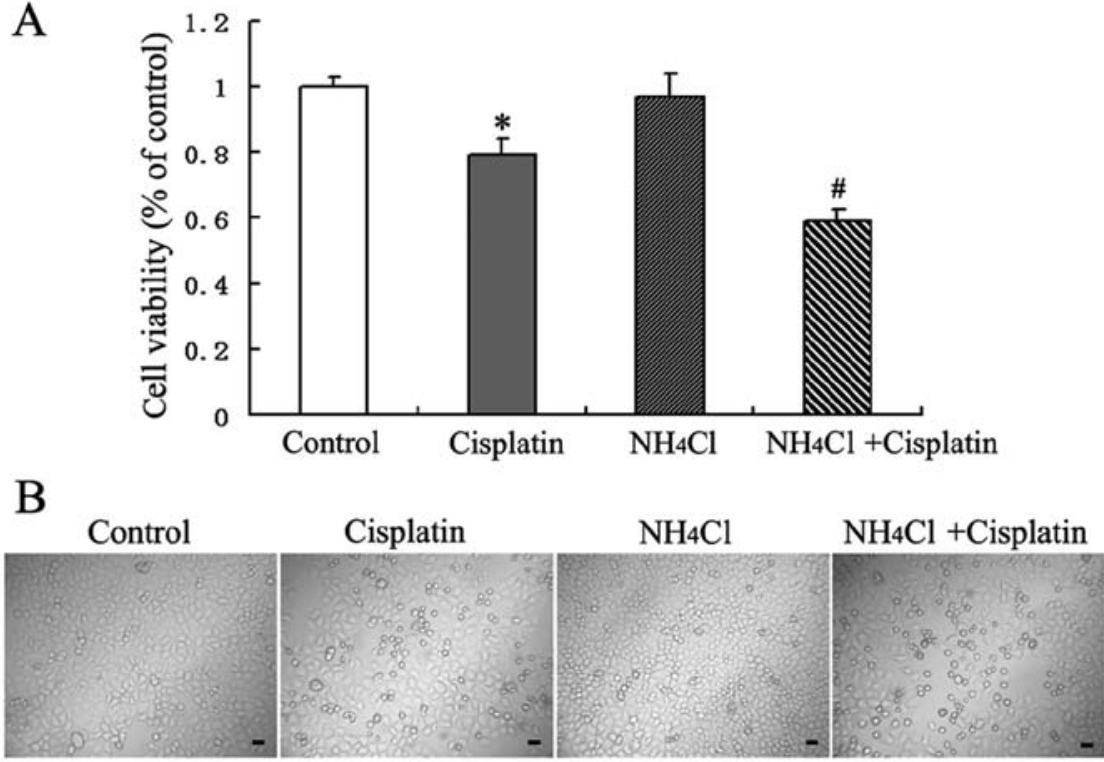

Figure 1. $\mathrm{NH}_{4} \mathrm{Cl}$ increases the growth inhibition rate induced by cisplatin in human cervical cancer (HCC) cells. HeLa cells were treated with cisplatin $(5 \mu \mathrm{g} / \mathrm{ml})$ and/or $\mathrm{NH}_{4} \mathrm{Cl}(2 \mathrm{mM})$ for $24 \mathrm{~h}$. (A) Cell viability was determined using MTT assay. (B) Images were captured using an inverted phase contrast microscope at a magnification of $x 100$. Data are expressed as means $\pm \mathrm{SD}, \mathrm{n}=3 .{ }^{*} \mathrm{P}<0.05$ vs. control cells; ${ }^{*} \mathrm{P}<0.05$ vs. cisplatin-treated cells.
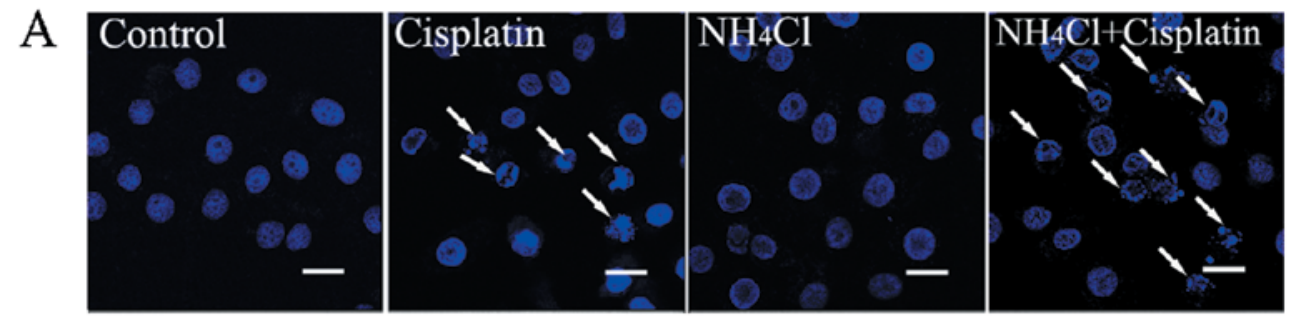

B
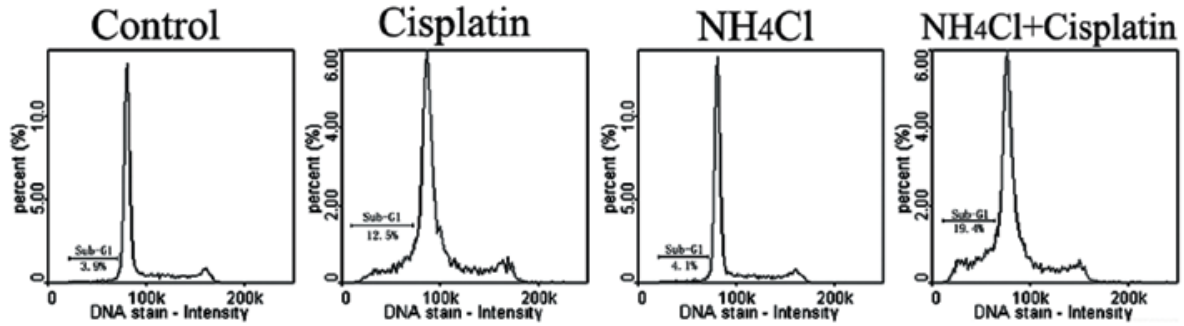

Figure 2. $\mathrm{NH}_{4} \mathrm{Cl}$ increases cisplatin-induced apoptosis. (A) HeLa cells were treated with cisplatin ( $\left.5 \mu \mathrm{g} / \mathrm{ml}\right)$ and/or $\mathrm{NH} / 4 \mathrm{Cl}(2 \mathrm{mM})$ for $24 \mathrm{~h}$, followed by staining with Hoechst 33342. Cell morphology was observed by confocal microscopy (bar, $10 \mu$ m; arrows indicate apoptotic cells). (B) HeLa cells were treated with cisplatin and/or $\mathrm{NH}_{4} \mathrm{Cl}$ for $24 \mathrm{~h}$, followed by staining with PI. The cell cycle was assessed using a FACScan flow cytometer. Sub-G1 peaks represent the percentages of apoptotic cells. Data are expressed as means $\pm \mathrm{SD}, \mathrm{n}=3$.

shown in Fig. 2B, a higher apoptotic rate (sub-G1 peak) was observed in cells treated with cisplatin combined with $\mathrm{NH}_{4} \mathrm{Cl}$ $(19.4 \%)$, when compared with the apoptotic rate of the cells treated with cisplatin alone $(12.5 \%)$.

$\mathrm{NH}_{4} \mathrm{Cl}$ combined with cisplatin increases the activation of caspase-3. Caspase-3 plays an important role in the execution of apoptosis, and its activation reflects the process of apoptosis. The activation of caspase- 3 in HeLa cells treated with cisplatin alone and cells treated with cisplatin combined with $\mathrm{NH}_{4} \mathrm{Cl}$ was assessed using confocal microscopy. Red fluorescence was more intense in cells treated with cisplatin combined with $\mathrm{NH}_{4} \mathrm{Cl}$ compared with cells treated with cisplatin alone, suggesting that treatment with the combination of cisplatin and $\mathrm{NH}_{4} \mathrm{Cl}$ increased the activation of caspase-3 (Fig. 3).

Furthermore, the activation of caspase- 3 was assessed by detecting the expression of cleaved caspase- 3 by western blot analysis. Cisplatin was found to increase the expression of cleaved caspase-3 in HeLa cells compared to control cells. However, treatment with cisplatin combined with $\mathrm{NH}_{4} \mathrm{Cl}$ increased the expression of cleaved caspase- 3 compared to cells treated with cisplatin alone (Fig. 4A and B). These results indicate that $\mathrm{NH}_{4} \mathrm{Cl}$ efficiently increased the apoptosis induced by cisplatin in HeLa cells. 


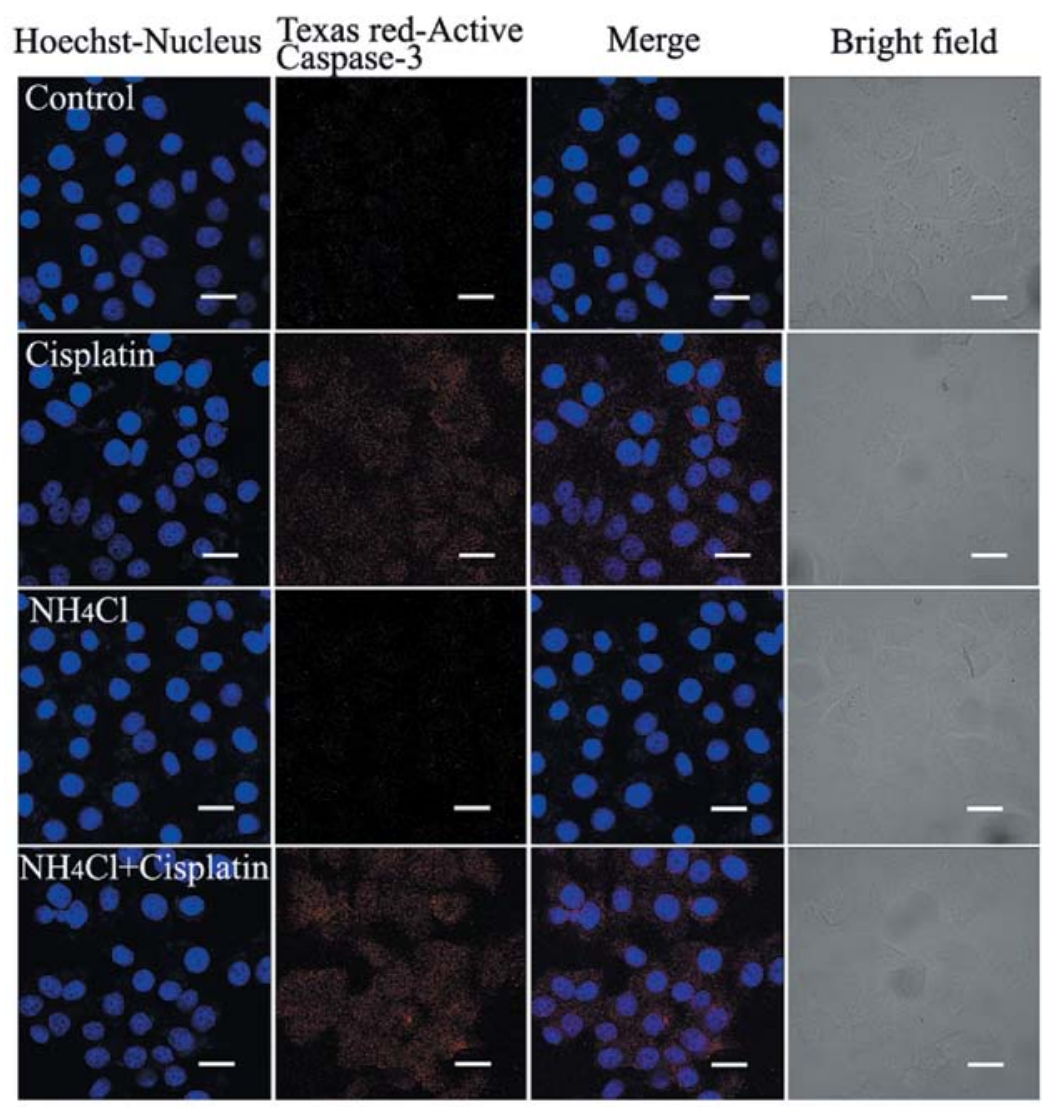

Figure 3. $\mathrm{NH}_{4} \mathrm{Cl}$ increases the expression of active caspase-3. HeLa cells were treated with cisplatin $(5 \mu \mathrm{g} / \mathrm{ml})$ and/or $\mathrm{NH}_{4} \mathrm{Cl}(2 \mathrm{mM})$ for $24 \mathrm{~h}$. The expression of active caspase- 3 was detected by confocal microscopy following the indicated treatments for $24 \mathrm{~h}$ (bar, $10 \mu \mathrm{m}$; Texas Red-conjugated secondary antibody).

A

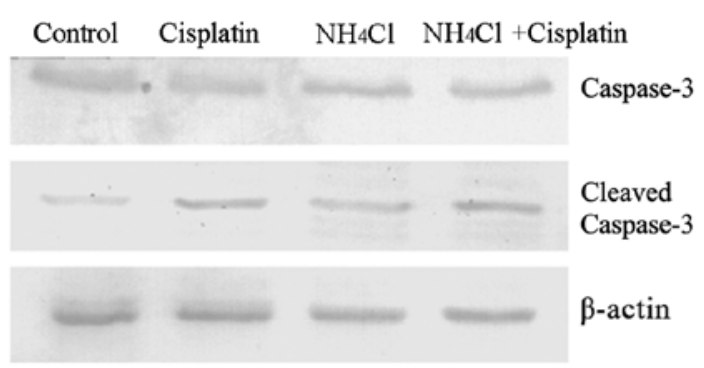

B

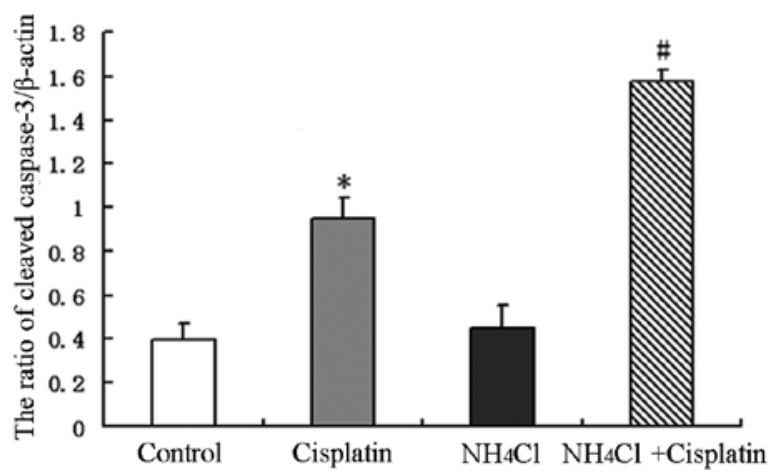

Figure 4. $\mathrm{NH}_{4} \mathrm{Cl}$ increases the activation of caspase-3. (A) HeLa cells were treated with cisplatin $(5 \mu \mathrm{g} / \mathrm{ml})$ and/or $\mathrm{NH}_{4} \mathrm{Cl}(2 \mathrm{mM})$ for $24 \mathrm{~h}$. Western blot analysis was performed to investigate the expression of caspase- 3 and cleaved caspase-3. (B) Quantitation of cleaved caspase-3 protein levels. Data are expressed as means $\pm \mathrm{SD}, \mathrm{n}=3$. ${ }^{*} \mathrm{P}<0.05$ vs. control cells; ${ }^{\#} \mathrm{P}<0.05$ vs. cisplatin-treated cells.
$\mathrm{NH}_{4} \mathrm{Cl}$ increases cisplatin-induced DNA DSBs. Cisplatin has been reported to kill cancer cells by damaging DNA and inhibiting DNA synthesis. Thus, we hypothesized that $\mathrm{NH}_{4} \mathrm{Cl}$ increases the DNA damage induced by cisplatin. DSBs induce the phosphorylation of $\mathrm{H}_{2} \mathrm{AX}$ at a conservative $\mathrm{C}$-terminal region of serine 139 leading to the formation of $\gamma-\mathrm{H}_{2} \mathrm{AX}$. Thus, $\gamma-\mathrm{H}_{2} \mathrm{AX}$ is usually used as a DNA DSB marker.

The expression of $\gamma-\mathrm{H}_{2} \mathrm{AX}$ in HeLa cells treated with cisplatin alone and cells treated with cisplatin combined with $\mathrm{NH}_{4} \mathrm{Cl}$ was determined using confocal microscopy (Fig. 5). After a 24-h treatment, green fluorescence was observed in cells treated with cisplatin alone. Moreover, less intense green fluorescence was observed in cells treated with $\mathrm{NH}_{4} \mathrm{Cl}$ alone compared with cisplatin-treated cells. The strongest green fluorescence was observed in cells treated with cisplatin combined with $\mathrm{NH}_{4} \mathrm{Cl}$ (Fig. 5). These results indicate that $\mathrm{NH}_{4} \mathrm{Cl}$ efficiently enhances DSBs induced by cisplatin in HeLa cells.

\section{Discussion}

Cisplatin is a widely used chemotherapeutic agent against several types of solid tumors, including cervical cancer, and is used either alone or in combination with other anticancer agents. However, the clinical use of cisplatin is limited due to its side-effects and drug resistance (17-19). The antitumor activity of cisplatin is attributed to its ability to cause DNA damage, leading to the subsequent induction of apoptosis (20-22). DNA is the primary biological target of cisplatin (22). The platinum 


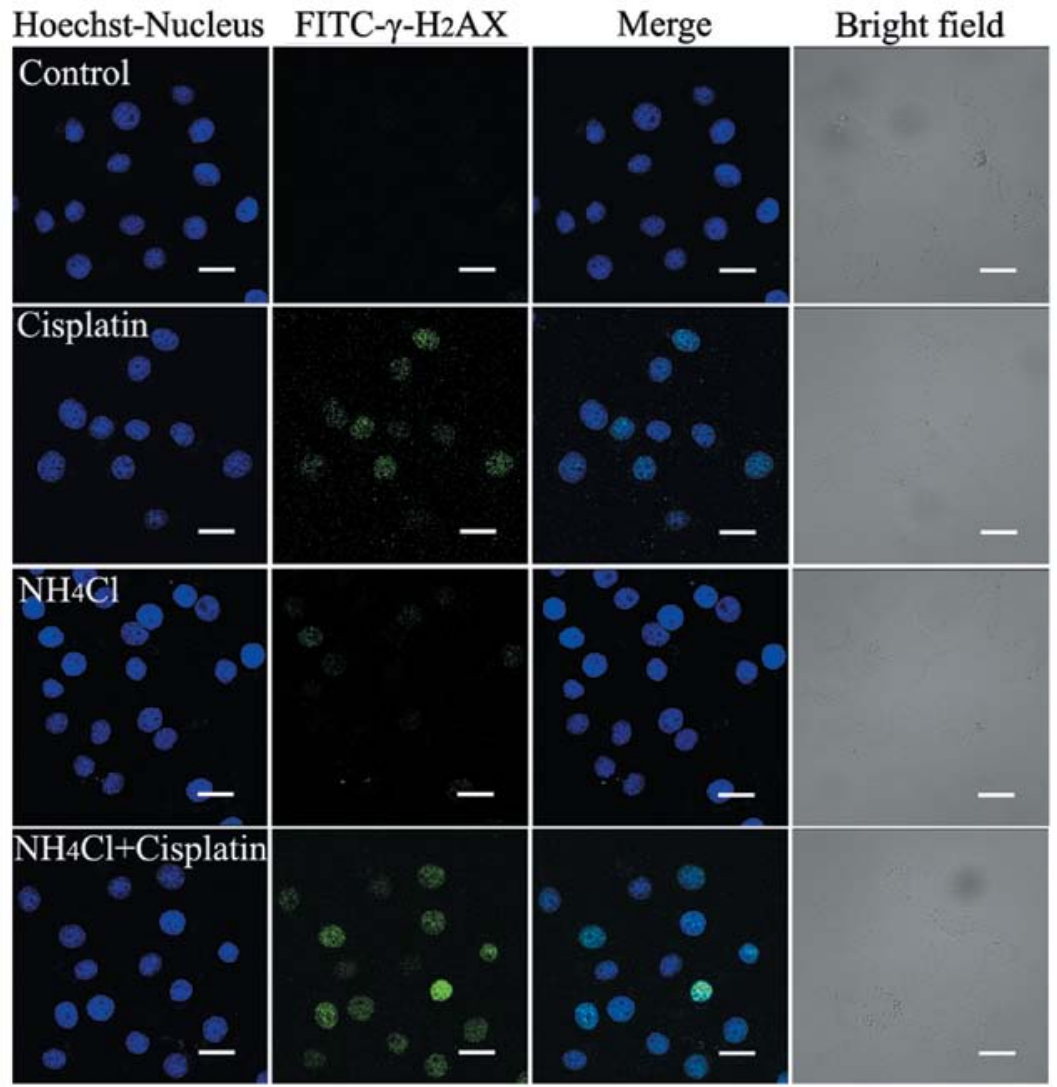

Figure 5. $\mathrm{NH}_{4} \mathrm{Cl}$ increases the phosphorylation of $\mathrm{H}_{2} \mathrm{AX}$. HeLa cells were treated with cisplatin $(5 \mu \mathrm{g} / \mathrm{ml})$ and/or $\mathrm{NH}_{4} \mathrm{Cl}(2 \mathrm{mM})$ for $24 \mathrm{~h}$. The expression of $\gamma-\mathrm{H}_{2} \mathrm{AX}$ was detected by confocal microscopy following the indicated treatments for $24 \mathrm{~h}$ (bar, $10 \mu \mathrm{m}$; FITC-conjugated secondary antibody).

atom of cisplatin forms covalent bonds with the N7 position of purine bases to form 1,2- or 1,3-intrastrand cross-links and a lower percentage of interstrand cross-links. The interstrand and intrastrand cross-links disrupt the structure of the DNA. Following DNA damage, cells either repair the damage and start progressing through the cell cycle or, when the damage cannot be repaired, the cells proceed to apoptosis (4). The main death pathway activated by specific cellular damage induced by cisplatin is a caspase-dependent intrinsic apoptotic pathway that involves mitochondria and the endoplasmic reticulum (ER) (7,23-27).

Apoptosis is a physiological process of cell self destruction, which plays important roles in embryo development, homeostasis and immune defense (28). Caspases are a group of proteases that are the key components involved in the process of apoptosis. Active caspase- 3 cleaves certain proteins and triggers the inactivation of cell structure-, cell cycle- and DNA repair-associated proteins or kinases, leading to cell apoptosis (29). $\mathrm{H}_{2} \mathrm{AX}$ phosphorylation occurs in response to replication fork damage caused by cisplatin-induced DNA lesions, probably interstrand cross-links. Although the early kinetics of $\gamma-\mathrm{H}_{2} \mathrm{AX}$ formation is uninformative, retention of $\gamma-\mathrm{H}_{2} \mathrm{AX}$ foci $24 \mathrm{~h}$ after treatment was shown to be a useful indicator of cell response to killing by cisplatin (30).

Cisplatin is a reactive drug that interacts not only with DNA, but also with proteins; damage to cytoplasmic proteins is an early process that has been suggested to initiate cisplatininduced apoptosis (31-33). The ER was recently reported to be a cytosolic target of cisplatin-induced apoptosis via the ER stress pathway; sustained and unabated ER stress induces caspase-mediated apoptosis $(7,27,34)$. In addition, ER stress and mitochondrial dysfunction have also been suggested to cooperatively regulate apoptotic-signaling cascades (35-37).

The results of the present study showed that cisplatin treatment inhibited cell growth and induced cell apoptosis. In addition, exposure to cisplatin activated caspase- 3 and increased phosphorylation of $\mathrm{H}_{2} \mathrm{AX}$. These findings collectively indicate that cisplatin induces apoptosis through DNA damage in HCC HeLa cells.

$\mathrm{NH}_{4} \mathrm{Cl}$, an expectorant, diuretic and systemic acidifying agent, is used in the treatment of severe metabolic alkalosis, to maintain the urine at an acidic $\mathrm{pH}$ in the treatment of certain urinary tract disorders or in forced acid diuresis (13). The excess ammonia $\left(\mathrm{NH}_{4} \mathrm{Cl}\right)$ interferes with brain energy metabolism possibly in part by inhibiting the tricarboxylic acid (TCA) cycle (38). In experimental studies, $\mathrm{NH}_{4} \mathrm{Cl}$ can be used as an autophagy inhibitor, which inhibits the activation of lysosomal enzymes, thus blocking the degradation of autolysosome components (14-16). According to a previous study by our group, $\mathrm{NH}_{4} \mathrm{Cl}$ was found to prevent autophagy flux by inhibiting the fusion of autophagosomes with lysosomes and to enhance apoptosis induced by menadione via the mitochondrial pathway. These results indicated the generation and accumulation of reactive oxygen species, as well as increased levels of ubiquitinated proteins and GRP78 in cells treated with both menadione and $\mathrm{NH}_{4} \mathrm{Cl}$ (16). In the present study, we 
found that $2 \mathrm{mM} \mathrm{NH}_{4} \mathrm{Cl}$ had no toxic effects on HeLa cells. Moreover, treatment with $\mathrm{NH}_{4} \mathrm{Cl}$ increased the apoptotic rate and the activation of caspase-3. Notably, $\mathrm{NH}_{4} \mathrm{Cl}$ treatment combined with cisplatin increased $\mathrm{H}_{2} \mathrm{AX}$ phosphorylation reflecting severe DNA damage.

In conclusion, cisplatin treatment was found to induce apoptosis and $\mathrm{H}_{2} \mathrm{AX}$ phosphorylation in HCC HeLa cells $\mathrm{NH}_{4} \mathrm{Cl}$ treatment combined with cisplatin increased cell growth inhibition rate, cell apoptosis rate and activation of caspase-3. Moreover, $\mathrm{NH}_{4} \mathrm{Cl}$ treatment increased $\mathrm{H}_{2} \mathrm{AX}$ phosphorylation induced by cisplatin. These findings indicate that $\mathrm{NH}_{4} \mathrm{Cl}$ could be potentially used as an effective agent for the improvement of cisplatin chemotherapy.

\section{Acknowledgements}

The present study was supported by the National Natural Science Foundation of China (no. 81100808), the Natural Science Foundation of Jilin Province (no. 201015240), the Department of Education of Jilin Province Project (no. 2013361), and Scientific Research Foundation of Jilin Medical College for University Students (201101).

\section{References}

1. Loehrer PJ and Einhorn LH: Drugs five years later. Cisplatin. Ann Intern Med 100: 704-713, 1984.

2. Woźniak $K$ and Błasiak J: Recognition and repair of DNA-cisplatin adducts. Acta Biochim Pol 49: 583-596, 2002.

3. Reedijk J: New clues for platinum antitumor chemistry: kinetically controlled metal binding to DNA. Proc Natl Acad Sci USA 100: 3611-3616, 2003.

4. Basu A and Krishnamurthy S: Cellular responses to cisplatininduced DNA damage. J Nucleic Acids 2010: 201367, 2010.

5. Liu D, Yang Y, Liu Q and Wang J: Inhibition of autophagy by 3-MA potentiates cisplatin-induced apoptosis in esophageal squamous cell carcinoma cells. Med Oncol 28: 105-111, 2011.

6. Kang R, Wang ZH, Wang BQ, et al: Inhibition of autophagypotentiated chemosensitivity to cisplatin in laryngeal cancer Hep-2 cells. Am J Otolaryngol 33: 678-684, 2012.

7. Xu Y, Yu H, Qin H, et al: Inhibition of autophagy enhances cisplatin cytotoxicity through endoplasmic reticulum stress in human cervical cancer cells. Cancer Lett 314: 232-243, 2012.

8. Kimura T, Takabatake Y, Takahashi A and Isaka Y: Chloroquine in cancer therapy: a double-edged sword of autophagy. Cancer Res 73: 3-7, 2013.

9. Elstrom RL, Andemariam B, Martin P, et al: Bortezomib in combination with rituximab, dexamethasone, ifosfamide, cisplatin and etoposide chemoimmunotherapy in patients with relapsed and primary refractory diffuse large B-cell lymphoma. Leuk Lymphoma 53: 1469-1473, 2012.

10. Kubicek GJ, Axelrod RS, Machtay M, et al: Phase I trial using the proteasome inhibitor bortezomib and concurrent chemoradiotherapy for head-and-neck malignancies. Int J Radiat Oncol Biol Phys 83: 1192-1197, 2012.

11. Ong PS, Wang XQ, Lin HS, Chan SY and Ho PC: Synergistic effects of suberoylanilide hydroxamic acid combined with cisplatin causing cell cycle arrest independent apoptosis in platinum-resistant ovarian cancer cells. Int J Oncol 40: 1705-1713, 2012.

12. Jin KL, Park JY, Noh EJ, Hoe KL, Lee JH, Kim JH and Nam JH: The effect of combined treatment with cisplatin and histone deacetylase inhibitors on HeLa cells. J Gynecol Oncol 21: 262-268, 2010.

13. Mathew JT and Bio LL: Injectable ammonium chloride used enterally for the treatment of persistent metabolic alkalosis in three pediatric patients. J Pediatr Pharmacol Ther 17: 98-103, 2012.

14. Kawai A, Uchiyama H, Takano S, Nakamura N and Ohkuma S: Autophagosome-lysosome fusion depends on the $\mathrm{pH}$ in acidic compartments in CHO cells. Autophagy 3: 154-157, 2007.
15. Yang YP, Liang ZQ, Gao B, Jia YL and Qin ZH: Dynamic effects of autophagy on arsenic trioxide-induced death of human leukemia cell line HL60 cells. Acta Pharmacol Sin 29: 123-134, 2008.

16. Yu C, Huang X, Xu Y, et al: Lysosome dysfunction enhances oxidative stress-induced apoptosis through ubiquitinated protein accumulation in Hela cells. Anat Rec (Hoboken) 296: 31-39, 2013.

17. Safirstein R, Winston J, Goldstein M, Moel D, Dikman S and Guttenplan J: Cisplatin nephrotoxicity. Am J Kidney Dis 8: 356-367, 1986.

18. Choudhury D and Ahmed Z: Drug-associated renal dysfunction and injury. Nat Clin Pract Nephrol 2: 80-91, 2006.

19. Alexander S, Swatson WS and Alexander H: Pharmacogenetics of resistance to cisplatin and other anticancer drugs and the role of sphingolipid metabolism. Methods Mol Biol 983: 185-204, 2013.

20. Sherman SE, Gibson D, Wang AH and Lippard SJ: X-ray structure of the major adduct of the anticancer drug cisplatin with DNA: cis-[Pt $\left.\left(\mathrm{NH}_{3}\right)_{2}\{\mathrm{~d}(\mathrm{pGpG})\}\right]$. Science 230: 412-417, 1985.

21. Chaney SG, Campbell SL, Bassett E and Wu Y: Recognition and processing of cisplatin- and oxaliplatin-DNA adducts. Crit Rev Oncol Hematol 53: 3-11, 2005.

22. Rebillard A, Lagadic-Gossmann D and Dimanche-Boitrel MT: Cisplatin cytotoxicity: DNA and plasma membrane targets. Curr Med Chem 15: 2656-2663, 2008.

23. Jiang $M$, Wang CY, Huang S, Yang $T$ and Dong Z: Cisplatininduced apoptosis in p53-deficient renal cells via the intrinsic mitochondrial pathway. Am J Physiol Renal Physiol 296: F983-F993, 2009.

24. Zhu J, Yang Y and Wu J: Bcl-2 cleavages at two adjacent sites by different caspases promote cisplatin-induced apoptosis. Cell Res 17: 441-448, 2007.

25. Sharma H, Sen S and Singh N: Molecular pathways in the chemosensitization of cisplatin by quercetin in human head and neck cancer. Cancer Biol Ther 4: 949-955, 2005.

26. Wei Q, Dong G, Franklin J and Dong Z: The pathological role of Bax in cisplatin nephrotoxicity. Kidney Int 72: 53-62, 2007.

27. Peyrou M, Hanna PE and Cribb AE: Cisplatin, gentamicin, and p-aminophenol induce markers of endoplasmic reticulum stress in the rat kidneys. Toxicol Sci 99: 346-353, 2007.

28. Hotchkiss RS, Strasser A, McDunn JE and Swanson PE: Cell death. N Engl J Med 361: 1570-1583, 2009.

29. Slee EA, Adrain C and Martin SJ: Executioner caspase-3, -6, and -7 perform distinct, non-redundant roles during the demolition phase of apoptosis. J Biol Chem 276: 7320-7326, 2001.

30. Olive PL and Banáth JP: Kinetics of $\mathrm{H}_{2} \mathrm{AX}$ phosphorylation after exposure to cisplatin. Cytometry B Clin Cytom 76: 79-90, 2009.

31. Fuertesa MA, Castillab J, Alonsoa C and Perez JM: Cisplatin biochemical mechanism of action: from cytotoxicity to induction of cell death through interconnections between apoptotic and necrotic pathways. Curr Med Chem 10: 257-266, 2003.

32. Gonzalez VM, Fuertes MA, Alonso C and Perez JM: Is cisplatin-induced cell death always produced by apoptosis? Mol Pharmacol 59: 657-663, 2001.

33. Perez RP: Cellular and molecular determinants of cisplatin resistance. Eur J Cancer 34: 1535-1542, 1998.

34. Mandic A, Hansson J, Linder S and Shoshan MC: Cisplatin induces endoplasmic reticulum stress and nucleus-independent apoptotic signaling. J Biol Chem 278: 9100-9106, 2003.

35. Ruiz A, Matute $C$ and Alberdi E: Intracellular $\mathrm{Ca}^{2+}$ release through ryanodine receptors contributes to AMPA receptor-mediated mitochondrial dysfunction and ER stress in oligodendrocytes. Cell Death Dis 1: e54, 2010.

36. Lee JW, Kim WH, Yeo J and Jung MH: ER stress is implicated in mitochondrial dysfunction-induced apoptosis of pancreatic beta cells. Mol Cells 30: 545-549, 2010.

37. Takemoto K, Miyata S, Takamura H, Katayama $\mathrm{T}$ and Tohyama M: Mitochondrial TRAP1 regulates the unfolded protein response in the endoplasmic reticulum. Neurochem Int 58: 880-887, 2011.

38. Haghighat N, McCandless DW and Geraminegad P: The effect of ammonium chloride on metabolism of primary neurons and neuroblastoma cells in vitro. Metab Brain Dis 15: 151-162, 2000 . 